\title{
Attainment Discrepancy Level, Firm Resources Slack, and Sticky Cost
}

\author{
Riha Dedi Priantana ${ }^{1}$, Abdul Rohman ${ }^{1} \&$ Fuad $^{1}$ \\ ${ }^{1}$ Business and Economics Faculty, Diponegoro University, Semarang, Indonesia \\ Correspondence: Riha Dedi Priantana, Postgraduate Student at Business and Economics Faculty, Diponegoro \\ University, Semarang, Indonesia.
}

Received: October 9, 2019

Accepted: November 14, 2019

Online Published: March 16, 2020

doi:10.5430/ijfr.v11n2p97

URL: https://doi.org/10.5430/ijfr.v11n2p97

\begin{abstract}
The aim of this study is to further develop the behavioral theory of the firm into the context of sticky cost research. The company's actions in managing resources can be explained through the concept of attainment discrepancy level and resource slack in the behavioral theory of the firm explaining the company's sticky costs. This study also examines the effect of attainment discrepancy levels, both historical and social, on cost behavior between slack dimensions and overall slack. To examine it, this study used 2,416 observations data from 302 companies listed on the Indonesian Stock Exchange during 2009-2017. Using Eviews 10, the estimation results of the regression model based on HAC find that the attainment of discrepancy level and resource slack affects sticky costs. Specifically, this study found that historical attainment discrepancy level causes sticky cost behavior to decrease, whereas social attainment discrepancy level increases cost behavior to become more sticky cost. The effect of resource slack on sticky cost behavior is reduced, both for each slack dimension and for the overall slack. Furthermore, the results show that the existence of certain types of slack, namely unabsorbed slack, increases the company's sticky cost behavior when it is associated with historical attainment discrepancy levels. To sum up, these results indicate that the firm makes internal business processes as the focus of attention in managing the company's resources. As a consequence, this situation can be used as an alternative explanation for the company's asymmetric cost behavior.
\end{abstract}

Keywords: sticky cost, attainment discrepancy level, unabsorbed slack, resources slack, behavioral theory of the firm

\section{Introduction}

Sticky cost has become an interesting research area for researchers in cost accounting in recent decades since it was first popularized by Anderson, Banker \& Janakiraman in 2003 (Banker, Byzalov, Fang, \& Liang, 2018; Banker \& Byzalov, 2014; Cannon, 2014; Han, Rezaee, \& Tuo, 2019; Weiss, 2010). Many motives that drive sticky cost, one of them is the explanation of the resource adjustment cost. The resource adjustment costs predict cause of sticky costs is based on the actions of the manager who considers aspects of the costs borne by the company when the company makes adjustments to resources when facing changes in the level of demand or sales, both when reducing resources in the period current or current addition of new resources in the coming period (Anderson et al., 2003; Banker \& Byzalov, 2014; Cannon, 2014; Weiss, 2010). These adjustment cost might include all company expenses, such as severance funds for termination of employment contracts, company expenses implicitly, and also decrease of employee morale on labor reduction, and loss of morale that has been built so far (Banker \& Byzalov, 2014; Kitching, Mashruwala, \& Pevzner, 2016).

The second perspective is the impetus of personal managerial interests based on agency costs, as opposed to explaining resource adjustment costs (Anderson et al., 2003; Banker \& Byzalov, 2014; Balakrishnan, Petersen \& Soderstrom, 2004; Cannon, 2014; Chen, Lu \& Sougiannis, 2012; Dierynck, Landsman \& Renders, 2012; Kama \& Weiss, 2013; Weiss, 2010). As an example, Chen at al. (2012) found strong evidence that sticky costs occur due to empire-building behavior found in manager's action, where the greater the nature of self-interested manager's consideration, the greater the occurrence of sticky costs in the firm costs' account. Dierynck et al. (2012) managed to empirically find out those companies with the ability to meet break-even earnings targets, neither profit nor loss, tended to have relatively small sticky costs. Such a company tends to reduce resources when sales increase and hold fewer resources when sales decline in order to achieve break-even earnings targets so that the pattern of cost changes becomes symmetrical. They also found out that companies that experienced little loss or had large profits showed a large sticky cost behavior. This condition occurs because the company wants to maintain a good company reputation thereby limiting the reduction in labor, and only adjusting the number of hours worked. 
Kama \& Weiss (2013) examined managers' motivation to achieve income targets more specifically by classifying them into 3 categories, namely encouraging to prevent income decline, to push for profit, to push back to profit or to produce. Kama \& Weiss (2013) found that to achieve certain earning targets that had encouraged managers to reduce resources excessively, especially when reducing sales rather than considering optimizing the interests of the company's value, thereby reducing the occurrence of sticky costs due to this decline is temporary. The act of accelerating the reduction of these resources is motivated by the drive to achieve earnings targets because when there is no encouragement to achieve these earnings targets, managers do not reduce resources when sales decline, which causes sticky costs to occur (Kama \& Weiss, 2013).

Based on the previous sticky cost research, most sticky cost research so far has been dominated by explanation of the cost of adjusting resources and agency theory (Armanto, Tiono, \& Suthiono, 2014; Balakrishnan et al., 2004; Cannon, 2014; Chen et al., 2012; Dierynck et al., 2012; Kama \& Weiss, 2013; Ratnawati \& Nugrahanti, 2015; Sugiri, Febrianto, \& Kresnawati, 2017; Weiss, 2010; Windyastuti, Sunaryo, \& Hastuti, 2017). These two conflicting theories give a different meaning about sticky cost itself. Therefore, the purpose of this current research is trying to identify alternative theories that can provide a complete picture of the occurrence of sticky costs. Kama \& Weiss (2013) argued that all efforts aimed at understanding the causes of changes in the company's cost structure cannot be separated from the motives and incentives of managers as decision-makers in allocating resources and internal drivers within the company. This study uses the company's internal business processes as managerial incentives for affecting sticky cost behavior, which is different from with managerial incentives for these determinants sticky costs from Dierynck et al. (2012, Chen et al. (2012) and Kama \& Weiss (2013).

Cyert \& March (1963) argue that the behavioral theory of the firm focuses more on the explanation of events and internal company events as the main basis in managerial decision making in the firm. The behavioral theory of the firm considers that the company with internal business processes, including the company's cost structure, cannot be separated from the role of managers in the company, especially the allocation of resources by managers. Anderson et al. (2003) also view that the occurrence of sticky cost is very closely related to direct manager intervention, and the sticky cost is also an occurrence at the company level.

Based on the explanation of Kama \& Weiss (2013), Cyert \& March (1963) and Anderson et al. (2003), the contribution of this study is the use of a framework of the behavioral theory of the firm, from the perspective of understanding the company's internal business processes to explain the company's sticky costs. In addition, the behavioral theory of the firm might be predicted to accommodate the conflicting theories in determinants sticky cost so that it could provide an additional alternative of the sticky cost phenomenon as a complete explanation complementing from previous research (Anderson et al., 2003; Balakrishnan, Petersen \& Soderstrom, 2004; Banker, Byzalov \& Chen, 2013; Cannon, 2014; Banker, Byzalov, Ciftci \& Mashruwala, 2014; Subramaniam \& Weidenmier, 2016; Dierynck et al., 2012; Chen et al., 2012; Kama \& Weiss, 2013; Banker \& Byzalov, 2014; Bugeja, Lu \& Shan, 2015).

An understanding of the characteristics of a company's internal business processes can be a medium for observing and investigating the pace of company development (Lin, Liu \& Cheng, 2011). The company's actions themselves are the response and results of managers' understanding of the company's internal business processes (Cyert \& March, 1963). Two important concepts in the behavioral theory of the firm that can be used as an analysis of manager's actions is attainment discrepancy level and resource slack (Cyert \& March, 1963; Lin, Liu, \& Cheng, 2011). Therefore, understanding these two concepts is an important issue for predicting overall corporate behavior in managing the company's internal business processes (Becerra, 2009; Bowen, 2007). Both of these concepts are directly related to the management of company resources and are the focus of the company's attention so it is believed to be able to influence the company's cost behavior.

Besides the framework of the behavioral theory of the firm, this study also carried out a direct measurement of resource slack empirically as another contributions. Most sticky cost studies so far have only provided theoretical explanations about resource slack as causes of sticky costs through full capacity utilization and the cost of resource adjustment except for Chen, Kama \& Lehavy (2018) (Anderson et al., 2003; Balakrishnan et al., 2004; Weiss, 2010; Cannon, 2014; Banker \& Byzalov, 2014). In addition, the observation period of this current study is from 2009 to 2017 so that it can complement the results of previous studies. Furthermore, the organization of the discussion of this article includes the literature review and development of hypotheses, the research methods used to answer research questions. Further discussion will relate to the findings and discussion of important findings, and conclusions on the entire research process. 


\section{Literature Review and Hypotheses Development}

\subsection{Sticky Cost}

Cost becomes sticky as an asymmetrical change in costs to changes in the level of a company's sales activity, that is, costs increase more when company sales increase than when sales decline (Anderson et al., 2003; Banker et al., 2018; Banker \& Byzalov, 2014; Han et al., 2019). In line with this definition, Cannon (2014) describes sticky costs as costs add up more quickly when sales increase; conversely, costs are reduced to slower when sales decline. Banker et al. (2014a) consider sticky costs as a smaller cost reduction over sales decline compared to an increase in costs when sales increase. Sticky cost can be interpreted as an unequal cost response to changes in the level of company activity so it is also known as asymmetric cost behavior (Anderson et al., 2003; Banker \& Byzalov, 2014).

Anderson et al. (2003) examined sales, general and administrative costs and statistically and significantly found that sales, general and administrative costs increased by an average of 0.55 per $1 \%$ increase in sales, but decreased by an average of 0.35 per $1 \%$ decrease in sales. Anderson et al. (2003) also succeeded in identifying the determinants of the asymmetric cost behavior based on the explanation of the resource adjustment cost theory, such as asset intensity, and labor intensity of the company, and also economic factors such as GNP growth.

After Anderson et al. (2003)'s research, various research groups have stimulated to investigate the sticky costs' phenomenon. Take for example, certain research groups examine the consistency of sticky costs from department level, company level, industry level and international comparisons (Balakrishnan et al., 2004; Bugeja et al., 2015; Calleja, Steliaros, \& Thomas, 2006; Subramaniam \& Weidenmier, 2016; Cohen, Karatzimas, \& Naoum, 2017). Cohen et al. (2017) conducted a study on managers at the Greek local government level and found that managers adjust administrative costs when revenue decline rapidly compared to when revenue increase; otherwise, adjusting provision costs quickly when sales increase rather than sales decreases so that these costs become asymmetrical.

Weiss (2010) explains sticky costs and anti-sticky costs in the context of capacity adjustment. These fixed costs arise when the company is already in full capacity. The anti-sticky costs state appear at greater and faster purchase costs at the time of a decrease in sales compared to an increase in sales (Balakrishnan et al., 2004; Weiss, 2010). The cause of anti-sticky costs is due to a decrease in sales along with the use of company resources that are still dependent on normal capacity or there is still a lot of excess capacity, then managers do increase the company's capacity to increase the ratio of increased sales (Balakrishnan et al., 2004; Weiss, 2010). In line with this explanation, Cannon (2014) found the behavior of anti-sticky costs arises when managers save more costs by reducing capacity when demand decreases compared to reducing capacity when demand grows.

Several studies have examined sticky cost's determinant from various perspectives (Dierynck et al., 2012; Chen et al., 2012; Hartlieb, Loy, \& Eierle, 2019; Kama \& Weiss, 2013; Yang, 2019). Hartlieb et al. (2019) used 165,995 company observations and proved evidence that central company managers with high social capital show significantly lower sticky costs, whereas social community capital prevents company managers from self-interest behavior so that the sticky cost level increases. Yang (2019) also proves that on average Australian companies experience anti-sticky costs, particularly when companies have limited earning management and intellectual capital efficiency. Moreover, he found that human capital efficiency provides the opportunity to increase the company's sticky costs. Therefore, this sticky cost research still has a great opportunity to become an interesting topic research for the next few years.

\subsection{Behavioral Theory of the Firm}

Behavioral theory of the firm becomes a milestone in management research because this theory succeeds in changing the view from prescriptive management theory and assumptions of classical economic theory (Cyert \& March, 1963; Greve \& Tea, 2018; Kaczmarek, 2017). Furthermore, Greve \& Tea (2018) argues that behavioral theory of the firm provides an explanation about when and how companies respond to their goals. Dong, March, \& Workiewicz (2017) explain that the behavioral theory of the firm help researchers to understand how companies make decisions, learn, adapt to the environment, and form collective efforts from each party within the company.

In more detail, behavioral theory of the firm considers that all company activities are the role of managers in understanding the company's internal business processes that cannot be separated from the decision-making process related to resource allocation (Cyert \& March, 1963; Greve \& Teh, 2018). Understanding the specific characteristics of the internal company can be used as an important factor to observe the development of the company itself (Lin et al., 2011; Greve \& Teh, 2018). According to Cyert \& March (1963), behavioral theory of the firm is a theory that explains companies based on the perspective of the behavior and actions of managers in the decision-making process internally.

Company activities can be explained through an understanding of the situation and conditions of managers in the 
decision-making process to organize the company (Kaczmarek, 2017). Menurut Kaczmarek (2017), the manager's most important function is the authority for company decision making. Based on behavioral theory of the firm, an understanding of the decision making process by managers is the most important key to understanding the company with the entire business process therein (Cyert \& March, 1963; Kaczmarek, 2017).

Becerra (2009) considers that behavioral theory of the firm is able to provide a realistic picture of the company through the important role of managers in making decisions to coordinate and manage inter-company internal structures. Becerra (2009) argues that a company's success in adjusting to the business environment is very much determined by the effective management of the company's internal structure through the accuracy of decision making, controlling, incentives, and determining the company's goals. The internal structure of the company is used as a foundation for behavioral theory of the firm to explain and predict the company's behavior itself (Becerra, 2009).

Another specific characteristic of the behavioral theory of the firm's view is the manager's important role in the company (Cyert \& March, 1963; Greve \& Teh, 2018; Kaczmarek, 2017; Tyler \& Caner, 2016). Futhermore, Tyler \& Caner (2016) argues that the managers' decision-making process aims to set organizational goals or aspirational levels based on measurable outcomes, such as financial performance, number of sales, innovation and product performance. These management actions are a key control of overall company activities with management functions inherent in managers.

In particular, the company's activity to conduct the problematic search or slack search is a reflection of the observations or concerns of managers by considering the discretionary that is owned by the manager himself (Becerra, 2009). The direction of the manager's actions is largely determined by the consideration of managerial values and managerial awareness in the decision-making process (Bowen, 2007).

\subsection{Attainment Discrepancy Level}

Based on behavioral theory of the firm's explanation, aspiration performance level is the focus of management's attention in managing the company's internal business processes as a consequence of the agreement of the company's internal parties (Cyert \& March, 1963; Chen \& Miller, 2007; Chen, 2008; Lin et al.., 2011). This is because the level of aspiration performance is also an important clue in determining resource allocation actions because it is the company's reference point in determining all business actions and activities and also the benchmark for achieving future performance (Cyert \& March, 1963; Chen, 2008).

The company's actual performance is not always the same as the aspiration performance level, sometimes resulting in a difference, both more and less, which is referred to as attainment discrepancy level (Lin et al., 2011; Shinkle, 2012). Attainment discrepancy level influences the manager's reaction to determine the direction of the company's overall behavior, both regarding operational activities and the company's strategic actions, starting from the search process to solve short-term problems, or looking for new innovative products or services, to corporate strategic actions (Labianca, Fairbank, Andrevski, \& Parzen, 2009; Shinkle, 2012; O’Brien \& David, 2014; Xu, Zhou, \& Du, 2019).

Companies with positive attainment discrepancy levels show the company's success in achieving aspiration performance levels, and the various response measures available can be taken by managers, both internally in the form of maintaining current period resources, innovation and changes to company strategies, and externally in the form of corporate actions, such as mergers and acquisitions at a broader level to increase the level of aspirational performance to be higher, again, by changing company activities, sometimes even involving changes that contain risks (Chen, 2008; Cyert \& March, 1963; Gavetti, Greve, Levinthal, \& Ocasio, 2012; Iyer \& Miller, 2008; Lant \& Hurley, 1999; Lin et al., 2011; Shinkle, 2012; Xu et al., 2019). Specifically, Xu et al. (2019) argue that companies with positive attainment discrepancy levels have a tendency to maintain their long-term advantages through high research and development expenditure.

Companies with negative attainment discrepancy levels are interpreted as a sign of failure because the company is considered not to have satisfactory performance in achieving the target level of aspiration performance (Lant \& Hurley, 1999; Chen, 2008; Gavetti et al., 2012; Eggers \& Suh, 2019). Iyer \& Miller (2008) found that the acquisition action at the corporate level is reduced when the actual performance is below the level of aspiration performance, so the company is only able to do a local search to improve business performance that is running. Most of the focus of the company's management attention is to focus more on finding solutions to the causes of performance degradation that are still below the level of aspiration performance (Cyert \& March, 1963; Eggers \& Suh, 2019). Specifically, Eggers \& Suh (2019) found that companies with negative attainment discrepancy levels might improve their 
performance again when the company has previous experience with the causes of this performance's decline. As a result of this condition, the company make local search for solutions to problems as well as solutions to expand the company's capabilities so that the company can get a positive performance (Eggers \& Suh, 2019).

The manager strives to make performance improvements so that the company can return to be able to reach the level of performance of these aspirations, sometimes the company management even decreases the target level of the aspirational performance itself when the actual performance achievement gap below the aspiration performance level is quite large (Chen, 2008; Cyert \& March, 19663; Eggers \& Suh, 2019; Iyer \& Miller, 2008; Gavetti et al., 2012; Labianca et al., 2009). Adjustments to these lower aspirational performance levels are made by the company so that previous actual performance experiences are not repeated in the next period and the company is expected to be able to achieve these new aspirational performance levels (Cyert \& March, 1963; Chen \& Miller, 2007; Eggers \& Suh, 2019; Xu et al., 2019). Based on this explanation, the following hypothesis is proposed:

H1: Attainment discrepancy level affects the sticky cost

\subsection{Slack Resources}

Behavioral theory of the firm views the company's resource slack as an overall excess of company resources, both actual and potential (George, 2005; Chen, 2008; Iyer \& Miller, 2008; Lin, Cheng, \& Liu, 2009; Carnes, Xu, Simon, \& Karadag, 2019). This excess resource can be in the form of financial surplus, such as cash budgets, excess inventory, unused capacity, including labor, unexploited opportunities, even including free time and the generosity of company managers itself (Chen, 2008; George, 2005; Iyer \& Miller, 2008; Nohria \& Gulati, 1996; Lin et al., 2009).

In general, resource slack is a buffer mechanism for (actual) resources in order for companies to adapt successfully to quickly adapt to changes in the environment quickly without disrupting the company's internal business processes that are still running (Bourgeois, 1981; Zhang, Li, Jiang, Zhang, Hu, \& Liu, 2018). In principle, Zhang et al. (2018) state that the existence of various slack resources can positively improve company performance. This is because slack resources provide a fast response for companies in the face of internal and external pressures and uncertainty of the business environment (Zhang et al. (2018).

The existence of resource slack also provides initiative and implementation for strategic change and innovation, as well as encouraging other creative behaviors in the internal company (Cyert \& March, 1963; Bourgeois, 1981; Chen, 2008; Iyer \& Miller, 2008; Lin et al., 2009). Lin et al. (2009) argue that resource slack opens opportunities for companies to enter new markets and compete globally. In line with this, Iyer \& Miller (2008) show that the existence of excess capacity for companies can increase search activities to obtain change and refreshment for the development of the company itself.

Companies with large resource slacks still have the capacity to increase initiative activities, and implement change and innovation, and are still able to encourage creative behavior (Chen, 2008; Iyer \& Miller, 2008; Lin et al., 2009). The greater the level of resource slack owned by the company, the greater the company's ability to improve positive performance (Cyert \& March, 1963; Bourgeois, 1981; Chen, 2008; Iyer \& Miller, 2008; Lin et al., 2009). Liao \& Long (2018) found that slack resources had a positive influence on environmentally friendly product innovations in selecting company CEOs. Furthermore, this positive effect also directs slack resources help the company to succeed in every environmental change (Liao \& Long, 2018).

Companies with small resource slack ownership do not have the flexibility to be able to adapt optimally to environmental changes because they have limited available resources. This company tends to focus only on selective corporate control so that the use of resources is more effective, even tend to make internal efficiency so that companies do not experience difficulties when facing changes in business activities (Chen, 2008). This limited resource slack causes the company to not have sufficient buffer mechanism to anticipate the cessation of the company's activities when adjustments are found to the company's internal processes (Bourgeois, 1981).

Related to the occurrence of sticky costs, on the basis of the slack level of these resources, company management attempts to maintain greater resources at a small slack level than a large slack level, causing a higher sticky cost level at a small slack level compared to the greater slack level. Companies with small resource slack also indicate the limited capacity to increase and change activities, even tend to conduct efficient use of resources strictly. This company tends not to immediately reduce unused resources when there is a decrease in sales for fear of being able to burden the company's internal business processes in the future when increasing sales resulting in funding for these resource shortages (Iyer \& Miller, 2008; Chen, 2008). This condition of the company causes high sticky cost behavior in companies with small resource slack compared to large slack. Based on this explanation, the research hypothesis proposed is as follows: 
$\mathrm{H}_{2}$ : Slack resources affect the sticky cost

\section{Research Methods}

\subsection{Data Collection Method}

The population of this study consists of data on annual reports of companies listed on the Indonesian Stock Exchange during the year 2009-2017 from the Bloomberg database, except financial companies.

Table 1. Sample's observation

\begin{tabular}{lllll}
\hline Sampling Criteria & $\begin{array}{l}\text { Merchandising's } \\
\text { firms }\end{array}$ & $\begin{array}{l}\text { Manufacture's } \\
\text { firms }\end{array}$ & $\begin{array}{l}\text { Service's } \\
\text { firms }\end{array}$ & Number \\
\hline Total Population & 122 & 151 & 178 & $\mathbf{4 5 1}$ \\
\hline (-) Delisting Firms & $(6)$ & $(5)$ & $(4)$ & $(15)$ \\
\hline (-) Firms taking merger or acquisition & & & $(2)$ & $(2)$ \\
\hline (-) Missing value & $(23)$ & $(14)$ & $(36)$ & $(73)$ \\
\hline (-) Outlier & $(25)$ & $(9)$ & $(25)$ & $(59)$ \\
\hline Number of sampling firms & $\mathbf{6 8}$ & $\mathbf{1 2 3}$ & $\mathbf{1 1 1}$ & $\mathbf{3 0 2}$ \\
\hline Number of firm-years observation & $\mathbf{5 4 4}$ & $\mathbf{9 8 4}$ & $\mathbf{8 8 8}$ & $\mathbf{2 , 4 1 6}$ \\
\hline
\end{tabular}

Source: Research Summary (2019)

Table 1 provides sample criteria for this research. One of the main things is observation must not do a merger or acquisition because the company has taken long-term action, while the aim of the research is to investigate the company's cost behavior in the short term.

As for the initial, there were 451 companies listed on the Indonesian Stock Exchange during 2009-2017. The final sample data used in this study was 2,416 observations from 302 companies after subtracting from the missing value and outlier. Most research samples consist of manufacturing firms (123), then service firms (111), and, merchandising firms (122).

\subsection{Model Specification Analysis}

This research uses a sticky cost regression model used by Chen at al. (2012) by carrying out several developments that are tailored to the objectives of this study. They argue that the use of interaction variables in the specification of this model aims to reduce the problem of multicollinearity and to compare the main effects of each standalone variable. Therefore, this research uses this following main model to investigate hypothesis:

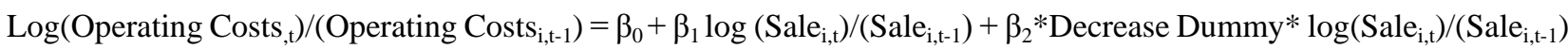
$+\beta_{3} *$ HisAtt.Des. $_{\mathrm{i}, \mathrm{*}}{ }$ Decrease Dummy* $\log \left(\mathrm{Sale}_{\mathrm{i}, \mathrm{t}} / \mathrm{Sale}_{\mathrm{i}, \mathrm{t}-1}\right)+\beta_{4}{ }^{*}$ SocAtt.Des. $_{\mathrm{it}}{ }^{*}$ Decrease Dummy* $\log \left(\mathrm{Sale}_{\mathrm{i}, \mathrm{t}} / \mathrm{Sale}_{\mathrm{i}, \mathrm{t}-1}\right)$ $+\beta_{5} *$ Total Slack $_{\mathrm{i}, \mathrm{t}} *$ Decrease Dummy $* \log \left(\right.$ Sale $_{\mathrm{i}, \mathrm{t}} /$ Sale $\left._{\mathrm{i}, \mathrm{t}-1}\right)+\beta_{6} *$ Employee Intensity $_{\mathrm{t}, \mathrm{t}} *$ Decrease Dummy $^{*}$ $\log \left(\right.$ Sale $\left._{\mathrm{i}, t} / \mathrm{Sale}_{\mathrm{i}, \mathrm{t}-1}\right)+\beta_{7} *$ Asset Intensity $_{\mathrm{it}} *$ Decrease Dummy $* \log \left(\right.$ Sale $\left._{\mathrm{i}, \mathrm{t}} / \mathrm{Sale}_{\mathrm{i}, \mathrm{t}-1}\right)+\beta_{8} *$ Successive Decrease $_{\mathrm{i}, \mathrm{t}} *$ Decrease Dummy $* \log \left(\operatorname{Sale}_{\mathrm{i}, \mathrm{t}} / \mathrm{Sale}_{\mathrm{i}, \mathrm{t}-1}\right)+\beta_{9} *$ Att.DesHis $_{\mathrm{i}, \mathrm{t}}+\beta_{10} *$ Att.Des.Sos $\mathrm{i}_{\mathrm{i}, \mathrm{t}}+\beta_{11} *$ Total Slack $_{\mathrm{i}, \mathrm{t}}+\beta_{12} *$ Employee Intensity $_{\mathrm{i}, \mathrm{t}}+\beta_{13} *$ Asset Intensity $_{\mathrm{i}, \mathrm{t}}+\beta_{14} *$ Successive Decrease $_{\mathrm{i}, \mathrm{t}}+\varepsilon_{\mathrm{t}}$

Where:

Operating cost and sale are total operating cost and sale revenue for firm i at year t. Decrease dummy has a value of 1 if sales in the period $\mathrm{t}$ are smaller than $\mathrm{t}-1$, otherwise 0 . Koefisien $\beta_{1}$ describes the percentage increase in operating costs for every 1 per cent increase in sales. The sum of coefficients $\beta_{1+} \beta_{2}$ indicates the percentage decrease in operating costs for every 1 per cent decrease in sales. Historical attainment discrepancy level is the difference between return on assets for firms $\mathrm{i}$ in years $\mathrm{t}$ and in years $\mathrm{t}-1$; Social attainment discrepancy level is a comparison between return on assets for firms in years $t$ and the median value of return on assets in the previous period ( $t-1)$ of all companies in one industry. Available slack is the number of total current assets divided by total current liabilities for firm i in year t. Potential slack is the ratio of total equity divided by total liabilities for firm i in year t. Unabsorbed slack is measured as totally free cash flow divided by total asset for firm i in year $t$, and free cash flow is derived from cash flow from operating activities- capital expenditures. Total slack is the index value obtained through factor analysis using 
principal-axis factor extraction based on oblique rotation. Employee intensity is the number of employees divided by total sale revenue; Asset intensity is the number of total assets divided by total sale revenue; Successive decrease is dummy variable that is equal to 1 if sale in year $t_{-1}$ is less than in $t_{-2}$, otherwise 0 .

\section{Result and Discussion}

\subsection{Descriptive Statistics}

Descriptive statistics of this research provide the average and median for the research variables.

Table 2. Summary descriptive statistics

\begin{tabular}{llllll}
\hline Variable(s) & Average & Median & Max & Min & Std. Dev \\
\hline Log (Operational Cost Changes) & 112.911 & 110.429 & 228.728 & 4.073 & 25.273 \\
\hline Log (Sale Changes) & 114.585 & 109.457 & $2,893.080$ & 0.559 & 70.494 \\
\hline Decrease Sale Changes & 23.307 & 0.000 & 100.000 & 0.000 & 38.675 \\
\hline Historical Attainment Discrepancy & -0.343 & -0.219 & 851.533 & -855.662 & 25.766 \\
\hline Social Attainment Discrepancy & 0.780 & 0.584 & 60.209 & -943.519 & 22.139 \\
\hline Available Slack & 318.34 & 144.65 & $46,498.44$ & 2.71 & $1,561.23$ \\
\hline Potential Slack & 611.72 & 100.76 & $402,809.00$ & $-2,013.46$ & $10,505.73$ \\
\hline Unabsorbed Slack & 288.83 & 0.77 & $580,925.20$ & $-19,484.53$ & $11,886.47$ \\
\hline Total Slack & -1.460 & -3.168 & 725.824 & -33.281 & 20.461 \\
\hline Employee Intensity & 0.145 & 0.072 & 7.100 & 0.000 & 0.263 \\
\hline Asset Intensity & 550.448 & 131.726 & $387,758.900$ & 11.863 & 8346.370 \\
\hline Successive Decrease & 11.631 & 0.000 & 100.000 & 0.000 & 32.066 \\
\hline Sour: Resen
\end{tabular}

Source: Research Summary (2019)

The average and median sale changes for firms are 114,585 and 109,457 as shown in Table 2. This table shows that Indonesian companies experienced a significant increase in sales compared to a decrease in sales. The operational cost changes also showed the same pattern of increase, namely the average and median increase in operational costs by 112,911 and 110,429. On average, 2,307 Indonesian companies experienced a decline in sales, while 76,693 experienced an increase in sales. This indicates that the company is very optimistic about the opportunity to increase the company's sales in the future, although sometimes the company experiences a decrease in sales in a certain period. In conclusion, changes in costs do not necessarily follow changes in sales, and costs even increase more when sales increase than sales decline, so-called sticky cost behavior (Anderson et al., 2003; Kama \& Weiss, 2013).

Historical attainment discrepancy has an average $(-0.342)$ and median $(-0.219)$ for the companies in the study sample. This result is different from social attainment discrepancy, where the average value is 0.780 and the median is 0.584 . This shows that Indonesian companies have lower historical performance compared to industrial (social) performance. This indicates that the performance of Indonesian companies has decreased compared to historical performance, although the same performance has a positive value when compared to the performance of all companies in the same industry (social performance).

Related to the slack variable, this study sample shows that the average company has a potential slack greater than other slack dimensions, which is equal to 611.72 with a median of 100.76 . These results indicate that Indonesian companies have large equity making it easier for companies to obtain new debt of 611.72 per cent of the current period debt. The same interpretation is also seen in other slack dimensions. The available slack has an average of 318.34 and a median of 144.65 , and the smallest average value is owned by an unabsorbed slack of 288.83 per cent with a median of 0.77 . Overall, the research sample has a large slack trend in managing the company's internal business.

\subsection{Analysis of Correlation}

This research do Pearson correlation test for all variables. The results of the research variables can be seen in Table 3 . 
Table 3.Correlation matrix

\begin{tabular}{|c|c|c|c|c|c|c|c|c|c|c|c|}
\hline Variable(s) & $\begin{array}{l}\text { Log } \\
\text { (Op.Co } \\
\text { st) }\end{array}$ & $\begin{array}{l}\text { Log } \\
\text { (Sale) }\end{array}$ & $\begin{array}{l}\text { His } \\
\text { Att.D } \\
\text { es }\end{array}$ & $\begin{array}{l}\text { Soc } \\
\text { Att.D } \\
\text { es }\end{array}$ & $\begin{array}{l}\text { Ava. } \\
\text { Slack }\end{array}$ & $\begin{array}{l}\text { Pot.S1 } \\
\text { ack }\end{array}$ & $\begin{array}{l}\text { Unab } \\
\text { s.Slac } \\
\mathrm{k}\end{array}$ & $\begin{array}{l}\text { Tot.S } \\
\text { lack }\end{array}$ & $\begin{array}{l}\text { Emp. } \\
\text { Int }\end{array}$ & $\begin{array}{l}\text { Ass.I } \\
\mathrm{nt}\end{array}$ & $\begin{array}{l}\text { Suc. } \\
\text { Dec }\end{array}$ \\
\hline Log (Op.Cost) & 1 & $.241^{* *}$ & .002 & $.061^{* *}$ & .009 & $.082^{* *}$ & -.007 & $.065^{* *}$ & $\begin{array}{l}-.074^{*} \\
*\end{array}$ & $.096^{* *}$ & $\begin{array}{l}-.197^{*} \\
*\end{array}$ \\
\hline Log (Sale) & $.241^{* *}$ & 1 & -024 & -.032 & $.186^{* *}$ & 026 & -.021 & $.064^{* *}$ & $-.066^{*}$ & -.008 & $\begin{array}{l}-.175^{*} \\
* *\end{array}$ \\
\hline His.Att.Des & .002 & -.024 & 1 & $.581^{* * *}$ & -.001 & .000 & $.628^{* *}$ & -.019 & .002 & .000 & -.028 \\
\hline Soc.Att.Des & $.061^{* *}$ & -.032 & $.581^{* *}$ & 1 & -.028 & -.008 & $\begin{array}{l}-.139^{*} \\
*\end{array}$ & -.014 & $\begin{array}{l}-.069^{*} \\
*\end{array}$ & -.016 & $-.107^{*}$ \\
\hline Ava.Slack & .009 & $.186^{* *}$ & -.001 & -.028 & 1 & $.366^{* *}$ & -.005 & $.718^{* *}$ & $.234^{* *}$ & $.369^{* *}$ & $.110^{* *}$ \\
\hline Pot.Slack & $.082^{* *}$ & -.026 & .000 & -.008 & $.366^{* *}$ & 1 & -.002 & $.910^{* *}$ & $.103^{* *}$ & $.847^{* * *}$ & $.071^{* *}$ \\
\hline Unabs.Slack & -.007 & -.021 & $.628^{* *}$ & $\begin{array}{l}-.139^{*} \\
*\end{array}$ & -.005 & -.002 & 1 & -.032 & -.011 & -.001 & -.009 \\
\hline Tot.Slack & $.065^{* *}$ & $.064^{* *}$ & -.019 & -.014 & $.718^{* *}$ & $.910^{* * *}$ & -.032 & 1 & $.182^{* * *}$ & $.796^{* * *}$ & $.102^{* *}$ \\
\hline Emp.Int & $-.074^{* *}$ & $-.066^{* *}$ & .002 & $\begin{array}{l}-.069^{*} \\
*\end{array}$ & $.234^{* *}$ & $.103^{* *}$ & -.011 & $.182^{* *}$ & 1 & $.184^{* *}$ & $.148^{* *}$ \\
\hline Ass.Int & $.096^{* *}$ & -.008 & .000 & -.016 & $.369^{* *}$ & $.847^{* *}$ & -.001 & $.796^{* *}$ & $.184^{* *}$ & 1 & $.084^{* *}$ \\
\hline Suc.Dec & $-.197^{* *}$ & $-.175^{* *}$ & -.028 & $-.107^{*}$ & $.110^{* *}$ & $.071^{* *}$ & -.009 & $.102^{* *}$ & $.148^{* *}$ & $.084^{* *}$ & 1 \\
\hline
\end{tabular}

*** Significance $\mathrm{p}$-value $<0.01, * * \mathrm{p}<0.05, * \mathrm{p}<0.1$, respectively

Source: Research Summary (2019)

In general, the results of the correlation test in Table 3 do not find multicollinearity problems between the independent variables and the dependent variable in this research model. Hair, Black, Babin, \& Anderson (2010) say that multicollinearity between variables becomes a problem when the Pearson correlation value is more than 90. For example, $\log$ (Sale) is significant with a correlation value of 0.186 with available slack, while the correlation with total slack also only 0.064 so that the correlation between the two independent variables does not become a disturbance in this regression model. Therefore, this research model is free of multicollinearity problems (Hair et al., 2010).

\subsection{Hypothesis Testing}

This study uses a regression model estimation based on HAC (Newey-West). Gujarati (2004) argues that the HAC (Newey-West) regression model is useful for overcoming regression models that contain heteroskedasticity and multicollinearity problems. Therefore, the estimated coefficient of research has been freed from the problems of these classic assumptions.

Table 4. Determinants of cost stickiness

\begin{tabular}{lcccc}
\hline Variable(s) & $\begin{array}{l}\text { Available } \\
\text { Slack }\end{array}$ & Potential Slack & $\begin{array}{l}\text { Unabsorbed } \\
\text { Slack }\end{array}$ & Total Slack \\
\hline Constant & $1.588066^{* * *}$ & $1.595592^{* * *}$ & $1.56685^{* * *}$ & $1.589275^{* * *}$ \\
\hline Log(sales changes) & $0.225264^{* * *}$ & $0.221334^{* * *}$ & $0.234871^{* * *}$ & $0.223867^{* * *}$ \\
\hline DecDummy*Log(sales changes) & $-0.014693^{* * *}$ & $-0.013999^{* *}$ & $-0.017132^{* * *}$ & $-0.012637^{* *}$ \\
\hline IndustryDummy & 0.00115 & 0.001162 & -0.001321 & 0.001128 \\
\hline Interaction terms (Variables* DecDummy*Log(sales changes) & & \\
\hline Historical Attainment Discrepancy & $0.000547^{* * *}$ & $0.000552^{* * *}$ & $-0.000964^{* *}$ & $0.000554^{* * *}$ \\
\hline
\end{tabular}




\begin{tabular}{|c|c|c|c|c|}
\hline Social Attainment Discrepancy & $-0.001231^{* * * *}$ & $-0.001206^{* * * *}$ & -0.000495 & $-0.001223^{* * * *}$ \\
\hline Available Slack & $0.00000365^{* *}$ & & & \\
\hline Potential Slack & & $5.55 \mathrm{E}^{-09 * * *}$ & & \\
\hline Unabsorbed Slack & & & $0.00000322^{* *}$ & \\
\hline Total Slack & & & & $0.000445^{* * *}$ \\
\hline Employee Intensity & -0.007338 & -0.005989 & -0.00283 & -0.006862 \\
\hline Asset Intensity & -0.00000101 & $-0.00000184^{* *}$ & $-7.63 \mathrm{E}^{-07}$ & $-0.00000158^{* * *}$ \\
\hline Successive Decrease & 0.0000203 & $-2.65 \mathrm{E}^{-08}$ & -0.0000116 & 0.0000121 \\
\hline \multicolumn{5}{|l|}{ Standalone Variables } \\
\hline Historical Attainment Discrepancy & $-0.000922^{* * *}$ & $-0.000927^{* * * *}$ & $-0.0012^{* * *}$ & $-0.000924^{* * * *}$ \\
\hline Social Attainment Discrepancy & $0.001054^{* * *}$ & $0.001059^{* * *}$ & $0.00127^{* * *}$ & $0.001058^{* * *}$ \\
\hline Available Slack & $-0.00000357^{*}$ & & & \\
\hline Potential Slack & & $-9.67^{-09}$ & & \\
\hline Unabsorbed Slack & & & $-4.72 \mathrm{E}^{-07}$ & \\
\hline Total Slack & & & & $-0.000383^{*}$ \\
\hline Employee Intensity & 0.013235 & 0.010291 & 0.012257 & 0.011796 \\
\hline Asset Intensity & $0.00000259^{* * *}$ & $0.00000287^{* * *}$ & $0.00000229^{* *}$ & $0.00000294^{* * * *}$ \\
\hline Successive Decrease & $-0.000191^{*}$ & $-0.000188^{*}$ & -0.0000711 & $-0.000193^{*}$ \\
\hline Adj. $R^{2}$ & 0.165981 & 0.165404 & 0.180204 & 0.166181 \\
\hline
\end{tabular}

*** Significance p-value $<0.01, * * \mathrm{p}<0.05, * \mathrm{p}<0.1$, respectively

Source: Research Summary (2019)

Tests in Table 4 show that operating costs increase more when a company's sales increase compared to when sales decrease. Company operational costs behave sticky cost. These results support the existence of sticky costs for company operating costs for slack dimensions and also total slack. The largest estimated value of $\beta 1$ is 0.23 for the significant unabsorbed slack at $\mathrm{p}$-value $1 \%$, which indicates that operating costs increase by $0.23 \%$ for every $1 \%$ increase in sales. The estimated value of $\beta 2$ for the unabsorbed slack is -0.02 which is also significant at p-value $1 \%$, which indicates that operating costs are reduced by $0.22 \%$ for every $1 \%$ decrease in sales. These results indicate that the level of sticky costs for operational costs in Indonesia is lower than in Australia and America (Bugeja et al., 2015; Anderson et al., 2003; Banker \& Byzalov, 2014).

\subsection{Historical Attainment Discrepancy}

After testing the presence of sticky costs in Indonesian companies, the next step is to investigate whether the level of sticky costs is influenced by the company's internal business processes, which are represented by attainment discrepancy levels and slack resources based on explanations and predictions of behavior theory of the firm. The estimation results of the regression for hypothesis testing are presented in Table 4. The effect of historical attainment discrepancy levels reduces the sticky cost level of the company's operating costs. The results of this test are consistent for all slack dimensions, except for the unabsorbed slack, where the estimated coefficient is -0.000964 and significant at the p-value of 5\%. For example, the effect of historical attainment discrepancy levels on operational costs becomes anti-sticky cost when testing total slack. This result is seen in the estimated coefficient of 0.000554 and significant at $\mathrm{p}$-value $1 \%$, as well as when testing the available and potential slack dimensions. This finding proves that the cost behavior becomes a little sticky cost when companies with historical attainment discrepancy level decrease. This is based on the manager's consideration to not immediately increase the additional slack when an increase in sales compared to a decrease in sales. Therefore, companies feel less interested in reducing resources when historical performance is achieved.

In general, the results of the historical attainment discrepancy test on the company's sticky cost level are significant in various types of slack resources, but with different coefficient direction. The results of this test indicate that historical 
attainment discrepancy can increase a company's sticky cost level, especially when the company has an unabsorbed slack. The findings of historical attainment discrepancy level are in line with the findings of sticky cost research so far, such as Banker, Byzalov, Ciftci, \& Mashruwala (2014) and Banker \& Byzalov (2014). For the first time, Banker et al. (2014) prove that the sticky cost and anti-sticky cost events are caused by events of the previous period, where an increase in sales of the previous period caused sticky costs, and a decrease in sales of the previous period increased the occurrence of anti-sticky costs. The Banker \& Byzalov (2014) argue that company managers become optimistic when sales increase in the previous period so that it encourages not to immediately adjust costs that occur in the current period and the occurrence of sticky costs occur; otherwise, when managers are pessimistic about the decline in sales of the previous period, then the manager encourages a decrease in the current period's resources and this causes anti-sticky costs.

Historical performance achievements make company managers pay attention to and sometimes keep up with changes in sales. By comparison of historical performance, operational costs are a little sticky cost for all slack resources, except for the unabsorbed slack. Companies with historical attainment discrepancy become more sticky cost levels when the company has free cash flow. The existence of this cash source provides a great opportunity for companies to increase short-term activities because the company has sufficient internal funding sources to support internal business processes. Therefore, companies increase committed resources to support increased sales and also maintain unemployment resources even though the company has decreased sales. This shows that the existence of this type of unabsorbed slack can reduce the level of sensitivity of the company's historical performance achievements. The company has free cash available to support all of the company's short-term activities.

This shows that the existence of free cash flow makes the company maintain slack resources when the company has decreased sales but dares to add new slack resources when the company has increased sales. This company's action makes the company's cost behavior sticky cost.

However, the company's actions become different when the company does not have the availability of unabsorbed slack in the form of free cash flow, such as available slack, potential slack, and overall slack. Company managers are very sensitive to changes in company sales when changes in sales are associated with historical performance achievements. This result is different from Calleja et al. (2006) proved that profitability (return on equity) did not affect the level of sticky cost in German, French, American and British companies. Their research proves that company performance, in general, has no effect on the company's sticky cost level.

The company follows the pattern of changing sales. For example, this research proves that the existence of large liquidity provides considerations to help reduce slack resources when sales decline; instead, companies add slack resources when sales increase. Company managers always pay attention and consider all the company's actions by making previous performance achievements as a benchmark. This is also reflected in the company's operational cost behavior, where the company does not immediately increase new resources when the company experiences an increase in sales; otherwise, the company is also trying to reduce unutilized resources when sales decline.

\subsection{Social Attainment Discrepancy}

Consistent with hypothesis 1 , this study empirically found that the sticky cost level of operational costs increased due to the attainment discrepancy level, especially in social industry comparison, with the estimated coefficient of -0.0012 and significant at a p-value of $1 \%$, except for testing the dimensions of the unabsorbed slack.

These results indicate that company managers have a strong desire to increase committed resources within the company when sales increase and still maintain unused resources even though the company has decreased sales as an alternative effort to maintain competition between companies in the same industry. The company will strive to maintain its existence and competitive spirit when the company is compared with other companies in the same industry. The company seeks to increase its competitive power by continuing to oversee other companies in the same industry.

In fact, the existence of the type of slack resources owned by the company is able to provide great opportunities to increase the company's sticky costs. Companies with social performance and also with short-term liquidity provide a great opportunity for companies to succeed in managing internal resources as an important step to support the company's industrial performance.

This is supported by the results of research by Iyer \& Miller (2008) who found that the danger of the company's acquisition actions will increase when the company's actual performance is above the level of aspiration, and then decreases. Furthermore, Iyer \& Miller (2008) prove empirically that a positive attainment discrepancy can be aimed at changing corporate strategies, such as mergers and acquisitions, and vice versa, when the company's performance is below the level of aspiration, the company is only able to do a local search to improve ongoing business performance. 
Specifically, the results of this study are also supported by Cheung, Kim, Kim and Huang's research (2018) conducting an asymmetry cost study related to the level of competition of 172,427 companies from 38 countries from 1990 to 2012. Their results prove that the competition factor increases opportunities company sticky costs occur where the level of company sticky costs increase when the company has high product differentiation, high entry costs and also a large market share.

The results of this study are also supported by the results of research Cheung et al. (2018) which proves that high product differentiation increases the chances of a sticky cost level of the company because the company has a high level of profitability margins so that it does not immediately reduce resources when sales decline. Li \& Zheng (2017) conducted a study of 50,735 observations of public companies from 1996-2009 and succeeded in proving that the level of competition was able to increase the company's sticky costs, especially in companies with high financial strength and managers who had high optimism. Li \& Zheng (2017) argue that companies with high product market competition try to maintain their competitive position, causing a slight reduction in resources when a decrease in sales and costs makes it more asymmetrical.

Hypothesis 2 test results show that the level of sticky cost is reduced when companies have slack resources, both in total slack and the slack dimension itself. These results are seen at the estimated value $0.00000365,5.55 \mathrm{E}-09$, 0.00000322 , and 0.000445 , and significant at $\mathrm{p}$-value $1 \%$ for available, potential, unabsorbed slack, and total slack, respectively. These results indicate that the greater slack resources owned by the company are associated with a smaller level of sticky cost on the behavior of the costs. These results are also consistent for each test of each type of slack and total slack. This finding can be interpreted as proving empirically that slack resources, both individually and in total, reduce the level of sticky costs in the company's cost behavior. Companies with slack resources are short-term, causing companies paying attention to declining sales. This indicates that the existence of slack resources makes the company has the capacity to manage internal resources more effectively so that the company is not motivated to increase new resources when sales increase and also does not try to reduce unused resources when sales decline.

The test results of the available slack and potential slack dimensions are in line with the research findings of Calleja et al. (2006), in which found that debt financing had no effect on the level of sticky costs in German, French, American and British companies. They argue that high levels of debt make the company become an object of attention by creditors so that it encourages companies to have great cost structure flexibility to anticipate changes in agreements that are very sensitive. Calleja et al. (2006) also proved that working capital showed an influence on the level of sticky costs in American and German companies, but did not affect British and French companies.

The results of this study also differ from those of Chen, Kama and Lehavy (2018) who examined 45,048 American public companies from 1994 to 2014 on the effect of the cost of adjusting resources and the availability of resource slack on managers' expectations of sticky costs and found that the level of sticky costs got stronger when resource slack is low, costs adjustments were high and optimistic manager expectations. Their research also found that if the cost of adjusting resources and availability of resource slack were low, followed by optimistic managers' expectations of increasing the occurrence of sticky costs, otherwise, if it coincided with pessimistic manager's expectations, the level of anti-sticky costs would be even higher.

This study found that control variables, such as asset intensity, were found to be significantly negative, increasing sticky cost levels on the company's operational cost behavior, with the estimated coefficient interaction -0.00000184 and -0.00000158 and significant at p-value $5 \%$ on testing the dimensions of potential slack and total slack. As for other control variables, such as employee intensity and successive decrease, this study failed to prove its influence on the level of sticky cost in the context of behavioral theory of the firm's explanation.

\section{Conclusion}

The main aim of this study is to examine the behavioral theory of the firm into the context of sticky cost determinants. Based on hypothesis testing, this study succeeded in proving that the level of sticky costs in the company's operational cost behavior is largely determined by the presence of the attainment discrepancy factor and slack resource of the company. Specifically, the effect of attainment discrepancy on sticky cost levels can vary, where historical attainment discrepancy levels cause sticky cost behavior to decrease, whereas social attainment discrepancy levels cause sticky cost behavior to increase. This study also proves that the existence of each type of slack and the overall slack itself causes sticky cost behavior in the company's cost behavior to also decrease. The findings of this study indicate that the focus of company actions is influenced by historical performance achievements and industry performance achievements (social performance), and slack resources as well. This provides evidence that the development of the company's internal business processes is getting major attention from the company. 
In fact, through this research, it can be proven that the important role of slack resources. For example, the level of sticky costs is reduced when companies with historical attainment discrepancy on all types of slack, except for unabsorbed slack. This type of slack specifically encourages companies to increase new committee resources when sales increase and still maintain unused resources when sales decline. This shows that slack resources provide their own capacity for companies to run internal business processes by following changes in sales.

The study also found that sticky costs were also experienced by the average companies listed on the Indonesian stock exchange from 2009-2017, but the level of sticky costs in companies in Indonesia was very low compared to sticky costs in companies in developed countries, such as Australia and America. Operating costs increase by $0.22-0.23 \%$ for every $1 \%$ rise in sales but operating costs decrease by $0.21-0.22 \%$ for every $1 \%$ decrease in sales.

In general, the findings of this study can be used for investors in evaluating company performance. First, the company is expected to pay attention to changes in sales by looking at performance achievements, both historical and social (industry), and also the availability of slack resources in responding to changes in sales so as to help companies in determining the right choice of short-term operational actions related to these performance achievements. Second, investors are expected to be able to understand the asymmetrical pattern of cost behavior as a rational action that must be taken by the company in responding to sales changes for the long-term goals of the company, not for the personal interests of the company's managers.

Based on the results, several limitations are also found in this study. First, this study has not yet concluded the effect of attainment discrepancy on sticky cost levels consistently. Therefore, future research should consider to include other related variables, such as the level of industry's competition, or also the effect of technological change between industries. Second, further research might use other quantitative approaches, such as using a questionnaire survey to company's managers to identify their response toward this sticky cost phenomenon. Third, further research can also use a variety of other measurements related to attainment discrepancy and slack resource variables because these measurement issues are an important consideration in order to get a clear picture of sticky cost itself.

\section{References}

Anderson, M. C., Banker, R. D., \& Janakiraman, S. N. (2003). Are Selling, General, and Administrative Costs "Sticky"?. Journal of Accounting Research, 41(1), 47-63. https://doi.org/10.1111/1475-679X.00095

Armanto, B., Tiono, K. M., \& Suthiono, H. (2014). The Stickiness of Selling, General, and Administrative Costs in the Indonesian Companies. International Research Journal of Business Studies, 7(1). https://doi.org/10.21632/irjbs.7.1.39-53

Balakrishnan, R., Petersen, M. J., \& Soderstrom, N. S. (2004). Does Capacity Utilization Affect the "Stickiness" of Cost?. Journal of Accounting, Auditing \& Finance, 19(3), 283-300. https://doi.org/10.1177/0148558X0401900303

Banker, R. D., \& Byzalov, D. (2014). Asymmetric Cost Behavior. Journal of Management Accounting Research, 26(2), 43-79. https://doi.org/10.2308/jmar-50846

Banker, R. D., Byzalov, D., \& Chen, L. T. (2013). Employment Protection Legislation, Adjustment Costs and Cross-Country Differences in Cost Behavior. Journal of Accounting and Economics, 55(1), 111-127. https://doi.org/10.1016/j.jacceco.2012.08.003

Banker, R. D., Byzalov, D., Ciftci, M., \& Mashruwala, R. (2014). The Moderating Effect of Prior Sales Changes on Asymmetric Cost Behavior. Journal of Management Accounting Research, 26(2), 221-242. https://doi.org/10.2308/jmar-50726

Banker, R. D., Byzalov, D., Fang, S., \& Liang, Y. (2018). Cost management research. Journal of Management Accounting Research, 30(3), 187-209. https://doi.org/10.2308/jmar-51965

Becerra, M. (2009). Theory of the Firm for Strategic Management: Economic Value Analysis. Cambridge University Press. https://doi.org/10.1017/CBO9780511626524

Bourgeois. (1981). On the Measurement of Organizational Slack. Academy of Management Review, 6(1), 29-39. https://doi.org/10.5465/amr.1981.4287985

Bowen. (2007). Corporate Social Strategy: Competing Views from Two Theories of the Firm. Journal of Business Ethics, 75(1), 97-113. https://doi.org/10.1007/s10551-006-9240-0

Bugeja, M., Lu, M., \& Shan, Y. (2015). Cost Stickiness in Australia: Characteristics and Determinants. Australian Accounting Review, 25(3), 248-261. https://doi.org/10.1111/auar.12066 
Calleja, K., Steliaros, M., \& Thomas, D. C. (2006). A Note on Cost Stickiness: Some International Comparisons. Management Accounting Research, 17(2), 127-140. https://doi.org/10.1016/j.mar.2006.02.001

Cannon, J. N. (2014). Determinants of "Sticky Costs": An Analysis of Cost Behavior Using United States Air Transportation Industry Data. The Accounting Review, 89(5), 1645-1672. https://doi.org/10.2308/accr-50806

Carnes, C. M., Xu, K., Sirmon, D. G., \& Karadag, R. (2019). How Competitive Action Mediates the Resource Slack - Performance Relationship: A Meta-Analytic Approach. Journal of Management Studies, 56(1), 57-90. https://doi.org/10.1111/joms.12391

Chen, C. L., Lu, H., \& Sougiannis, T. (2012). The Agency Problem, Corporate Governance, and the Asymmetrical Behavior of Selling, General, and Administrative Costs. Contemporary Accounting Research, 29(1), 252-282. https://doi.org/10.1111/j.1911-3846.2011.01094.x

Chen, J. V., Kama, I., \& Lehavy, R. (2018). A Contextual Analysis of the Impact of Managerial Expectations on Asymmetric Cost Behavior (June 2018). Ross School of Business Paper No. 1292. http://doi.org/10.2139/ssrn.2684164

Chen, W. R. (2008). Determinants of Firms' Backward-and Forward-Looking R\&D Search Behavior. Organization Science, 19(4), 609-622. https://doi.org/10.1287/orsc.1070.0320

Chen, W. R., \& Miller, K. D. (2007). Situational and Institutional Determinants of Firms' R\&D Search Intensity. Strategic Management Journal, 28(4), 369-381. https://doi.org/10.1002/smj.594

Cheung, J., Kim, H., Kim, S., \& Huang, R. (2018). Is the asymmetric cost behavior affected by competition factors?.

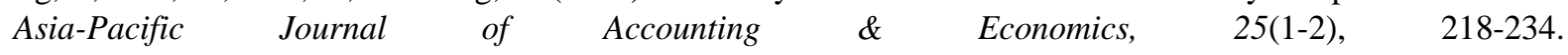
https://doi.org/10.1080/16081625.2016.1266271

Cohen, S., Karatzimas, S., \& Naoum, V. C. (2017). The sticky cost phenomenon at the local government level: Empirical evidence from Greece. Journal of Applied Accounting Research, 18(4), 445-463. https://doi.org/10.1108/JAAR-03-2015-0019

Cyert, R. M., \& March, J. G. (1963). A Behavioral Theory of the Firm. Englewood Cliffs.

Dierynck, B., Landsman, W. R., \& Renders, A. (2012). Do Managerial Incentives Drive Cost Behavior? Evidence About the Role of the Zero Earnings Benchmark for Labor Cost Behavior in Private Belgian Firms. The Accounting Review, 87(4), 1219-1246. https://doi.org/10.2308/accr-50153

Dong, J., March, J. G., \& Workiewicz, M. (2017). On organizing: an interview with James G. March. Journal of Organization Design, 6(1), 14. https://doi.org/10.1186/s41469-017-0024-z

Eggers, J. P., \& Suh, J. H. (2019). Experience and Behavior: How Negative Feedback in New Versus Experienced Domains Affects Firm Action and Subsequent Performance. Academy of Management Journal, 62(2), 309-334. https://doi.org/10.5465/amj.2017.0046

Gavetti, G., Greve, H. R., Levinthal, D. A., \& Ocasio, W. (2012). The Behavioral Theory of the Firm: Assessment and Prospects. The Academy of Management Annals, 6(1), 1-40. https://doi.org/10.5465/19416520.2012.656841

George, G. (2005). Slack Resources and the Performance of Privately Held Firms. Academy of Management Journal, 48(4), 661-676. https://doi.org/10.5465/amj.2005.17843944

Greve, H. R., \& Teh, D. (2018). Goal selection internally and externally: A behavioral theory of institutionalization. International Journal of Management Reviews, 20, S19-S38. https://doi.org/10.1111/ijmr.12138

Gujarati, D. N. (2004). Basic Econometrics. New York. https://doi.org/10.1126/science.1186874

Hair, J. F., Black, W. C., Babin, B. J., \& Anderson, R. E. (2010). Multivariate Data Analysis (Pearson Higher Ed.). https://doi.org/10.1016/j.ijpharm.2011.02.019

Han, S., Rezaee, Z., \& Tuo, L. (2019). Is cost stickiness associated with management earnings forecasts?. Asian Review of Accounting. https://doi.org/10.1108/ARA-04-2018-0096

Hartlieb, S., Loy, T. R., \& Eierle, B. (2019). Does community social capital affect asymmetric cost behaviour?. Management Accounting Research, 44, 1-58. https://doi.org/10.1016/j.mar.2019.02.002

Iyer, D. N., \& Miller, K. D. (2008). Performance Feedback, Slack, and the Timing of Acquisitions. Academy of Management Journal, 51(4), 808-822. https://doi.org/10.5465/AMJ.2008.33666024

Kaczmarek, S. (2017). Rethinking board diversity with the behavioural theory of corporate governance: 
opportunities and challenges for advances in theorising. Journal of Management \& Governance, 21(4), 879-906. https://doi.org/10.1007/s10997-016-9362-4

Kama, I., \& Weiss, D. (2013). Do Earnings Targets and Managerial Incentives Affect Sticky Costs?. Journal of Accounting Research, 51(1), 201-224. https://doi.org/10.1111/j.1475-679X.2012.00471.x

Kitching, K. A., Mashruwala, R., \& Pevzner, M. (2016). Culture and Cost Stickiness: A Cross-Country Study. International Journal of Accounting. https://doi.org/10.1016/j.intacc.2016.07.010

Labianca, G., Fairbank, J. F., Andrevski, G., \& Parzen, M. (2009). Striving toward the Future: Aspiration-Performance Discrepancies and Planned Organizational Change. Strategic Organization, 7(4), 433-466. https://doi.org/10.1177/1476127009349842

Lant, T. K., \& Hurley, A. E. (1999). A Contingency Model of Response to Performance Feedback Escalation of Commitment and Incremental Adaptation in Resource Investment Decisions. Group \& Organization Management, 24(4), 421-437. https://doi.org/10.1177/1059601199244002

Li, W. L., \& Zheng, K. (2017). Product market competition and cost stickiness. Review of Quantitative Finance and Accounting, 49(2), 283-313. https://doi.org/10.1007/s11156-016-0591-Z

Liao, Z., \& Long, S. (2018). CEOs' regulatory focus, slack resources and firms' environmental innovation. Corporate Social Responsibility and Environmental Management, 25(5), 981-990. https://doi.org/10.1002/csr.1514

Lin, W.-T., Cheng, K.-Y., \& Liu, Y. (2009). Organizational Slack and Firm's Internationalization: A Longitudinal Study of High-Technology Firms. Journal of World Business, 44(4), 397-406. https://doi.org/10.1016/j.jwb.2008.11.003

Lin, W.-T., Liu, Y., \& Cheng, K.-Y. (2011). The Internationalization and Performance of a Firm: Moderating Effect of a Firm's Behavior. Journal of International Management, 17(1), 83-95. https://doi.org/10.1016/j.intman.2010.12.004

Nohria, N., \& Gulati, R. (1996). Is Slack Good or Bad for Innovation?. Academy of Management Journal, 39(5), 1245-1264. https://doi.org/10.5465/256998

O'Brien, J. P., \& David, P. (2014). Reciprocity and R\&D Search: Applying the Behavioral Theory of the Firm to a Communitarian Context. Strategic Management Journal, 35(4), 550-565. https://doi.org/10.1002/smj.2105

Ratnawati, L., \& Nugrahanti, Y. W. (2015). Perilaku Sticky Cost Biaya Penjualan, Biaya Administrasi dan Umum Serta Harga Pokok Penjualan Pada Perusahaan Manufaktur. Jurnal Ekonomi dan Bisnis, 18(2). https://doi.org/10.24914/jeb.v18i2.314

Shinkle, G. A. (2012). Organizational Aspirations, Reference Points, and Goals Building on the Past and Aiming for the Future. Journal of Management, 38(1), 415-455. https://doi.org/10.1177/0149206311419856

Subramaniam, C., \& Weidenmier, M. (2016). Additional Evidence on the Sticky Behavior of Costs. In Advances in Management Accounting (pp. 275-305). Emerald Group Publishing Limited. https://doi.org/10.1108/S1474-787120150000026006

Sugiri, S., Febrianto, R., \& Kresnawati, E. (2017). Sticky cost behavior of bank's executive compensation in four South East Asian countries. Journal of Economics, Business \& Accountancy Ventura, 19(3), 363-376.

Tyler, B. B., \& Caner, T. (2016). New product introductions below aspirations, slack and R\&D alliances: A behavioral perspective. Strategic Management Journal, 37(5), 896-910. https://doi.org/10.1002/smj.2367

Weiss, D. (2010). Cost Behavior and Analysts' Earnings Forecasts. The Accounting Review, 85(4), 1441-1471.

Windyastuti, W., Sunaryo, K., \& Hastuti, S. (2017). Respon Investor Terhadap Pengumuman Laba Industri Perbankan yang Menghadapi Kos Stickiness. Jurnal Keuangan dan Perbankan, 21(1).

Xu, D., Zhou, K. Z., \& Du, F. (2019). Deviant versus aspirational risk taking: The effects of performance feedback on bribery expenditure and R\&D intensity. Academy of Management Journal, 62(4), 1226-1251.

Yang, Y. (2019). Do Accruals Earnings Management Constraints and Intellectual Capital Efficiency Trigger Asymmetric Cost Behaviour? Evidence from Australia. Australian Accounting Review, 29(1), 177-192.

Zhang, Y., Li, J., Jiang, W., Zhang, H., Hu, Y., \& Liu, M. (2018). Organizational structure, slack resources and sustainable corporate socially responsible performance. Corporate Social Responsibility and Environmental Management, 25(6), 1099-1107. https://doi.org/10.1002/csr.1524 